\title{
The efficiency and effectiveness of public policy using the system of indicators
}

\author{
Gulnara K. Kurmanova ${ }^{1}$, Bibigul B. Sukhanberdina' ${ }^{2}$, Bakit A. Urazova ${ }^{3}$, \\ Samal A. Mashanova ${ }^{4}$, Sholpan D. Salimbaeva ${ }^{5}$
}

\author{
Received: June 03, 2020 Revised: July 15, 2020 Accepted: July 30, 2020
}

\section{Түйін}

Қазақстан Республикасының одан әрі көпвекторлы дамуы жоспарланған макроэкономикалық көрсеткіштерге қол жеткізу мақсатында мемлекеттік қаржы ресурстарын жоғары нәтижелі пайдалану сияқты қаржы саясатының бағытына байланысты. Мемлекеттік шығыстарды басқарудың тиімділігі мәселелері - елдің бюджеттік құрылымына қарамастан барлық елдердегі бюджет саясатының квинтэссенциясы.

Теориялық және эмпирикалық базаны шолудың қол жеткізілген деңгейі индикаторлық жүйе негізінде бюджет саясатын іске асыру тетігін негіздеу үшін қызметтің ғылыми өрісін көрсетеді. Зерттеудің әдіснамалық негізін жұмыстың мақсатына (талдау, синтез) қол жеткізу үшін жалпы ғылыми талдау әдістерінің жиынтығы, экономикалық және статистикалық талдаудың қазіргі заманғы әдістері құрады.

Мақалада «Азаматтық бюджет» статистикалық деректері негізінде жергілікті бюджеттің қаржылық тұрақтылығы индикаторларының вариативті талдауы жүзеге асырылды, бюджеттің нақты шығыстары мен әлеуметтік саясатқа әсер ету арасындағы корреляциялық байланыс есептелген. Динамикалық есептеулерде мынадай көрсеткіштер - бюджеттік симметрия индикаторлары, кіріс әлеуетінің индикаторлары, бюджеттік қамтамасыз ету индикаторлары пайдаланылды. Индикаторлардың шекті мәндері, атап айтқанда, Батыс Қазақстан облысының бюджеті үшін кіріс әлеуеті, бюджеттік қамтамасыз етілуі сан жағынан есептелген және негізделген. Бюджеттік индикаторлар қаржылық жағдайдың үш деңгейінің қайсысына талданып отырған жергілікті бюджет жататынын анықтауға мүмкіндік берді.

Нәтижеге бағдарланған бюджеттеу (бұдан әрі - НББ) жүргізілген бюджеттік шығыстарға сәйкес тиімді нәтижелерге қол жеткізу мақсатында ұйымдарға, халыққа бюджеттік қызметтер көрсету арқылы бюджет қаражатын мемлекеттік саясаттың басты тармақтары бойынша нысаналы бөлуге әкелетін бюджет шығыстарын басқарудың осындай әдісі болып табылады деп айтуға болады.

Түйін сөздер: бюджет, бюджеттік шығындар, бюджеттік саясат, тиімділігі, нәтижелілігі, индикатор, жоспарлау.

\section{Аннотация}

Дальнейшее многовекторное развитие Республики Казахстан зависит от такого направления финансовой политики, как высокорезультативное использование государственных финансовых ресурсов с целью достижения запланированных макроэкономических показателей. Вопросы эффективности управления государственными расходами - квинтэссенция бюджетной политики во всех странах независимо от бюджетного устройства страны.

Достигнутый уровень обзора теоретической и эмпирической базы очерчивает научное поле деятельности для обоснования механизма реализации бюджетной политики на основе индикаторной системы. Методологическую основу исследования составила совокупность общенаучных аналитических методов для достижения цели работы (анализ, синтез), современных методов экономического и статистического анализа.

В статье на основе статистических данных «Гражданский бюджет» осуществлен вариативный анализ индикаторов финансовой устойчивости местного бюджета, рассчитана корреляционная связь между фактическими расходами бюджета и влиянием на социальную политику. В динамических расчетах использованы следующие показатели - индикаторы бюджетной симметрии, индикаторы доходного потенциала, индикаторы бюджетной обеспеченности. Количественно рассчитаны и обоснованы пороговые значения индикаторов, а именно доходного потенциала, бюджетной обеспеченности для бюджета Западно-Казахстан-

1 Associate Professor of the Department of Accounting and Finance, Candidate of Economic Sciences, West Kazakhstan Innovativetechnological University, Uralsk, e-mail:gulnara.ru@mail.ru, ORCID iD: https://orcid.org/0000-0002-9052-2990

2 Associate Professor of the Department of Accounting and Finance, Candidate of Economic Sciences, West Kazakhstan Innovativetechnological University, Uralsk, e-mail:suhanb@mail.ru, ORCID iD: https://orcid.org/0000-0002-8375-6350

3 Senior Lecturer, Department of Economics and Management, Master of Economics, West Kazakhstan Innovative-technological University, Uralsk, e-mail: kabdenova.68@mail.ru, ORCID iD: https://orcid.org/0000- 0001-9284-3301

4 Senior Lecturer, Department of Economics and Management, Master of Economics, West Kazakhstan Innovative-technological University, Uralsk, e-mail: samal.kz@mail.ru, ORCID iD: https://orcid.org/0000-0001-5110-2910

5 Senior Lecturer, Department of Accounting and Finance, Master of Economics, West Kazakhstan Innovative-technological University, Uralsk, e-mail:sh.salimbaeva@mail.ru, ORCID iD: https://orcid.org/0000-0001-6327-3469 
ской области. Бюджетные индикаторы позволили определить, к какому из трех уровней финансового состояния относится анализируемый местный бюджет.

Можно утверждать, что бюджетирование, ориентированное на результат, является таким методом управления расходами бюджета, который приводит к целевому распределению бюджетных средств по главным пунктам государственной политики, через предоставление бюджетных услуг организациям, населению с целью достижения эффективных результатов в соответствии с произведенными бюджетными расходами.

Ключевые слова: бюджет, бюджетные расходы, бюджетная политика, эффективность, результативность, индикатор, планирование.

\section{Abstract}

The multi-vector development of the Republic of Kazakhstan depends on such a direction of financial policy as a highly effective use of public financial resources in order to achieve the planned macroeconomic indicators. Issues of efficiency of public expenditure management are the quintessence of budget policy in all countries, regardless of the country's budget structure.

The achieved level of review of the theoretical and empirical base outlines the scientific field justifying the mechanism for implementing budget policy based on the indicator system. The methodological basis of the research is a set of general scientific analytical methods aimed to achieve the goal of the task (analysis, synthesis), modern methods of economic and statistical analysis.

In the article, based on the statistical data in the field of Civil budget, a variable analysis of financial stability indicators, connected with the local budget, is carried out, also there is a correlation between actual budget expenditures and the impact on social policy. There are following indicators used in dynamic calculations - indicators of budget symmetry, indicators of revenue potential, indicators of budget security. The threshold values of indicators, namely, revenue potential, budget security for the budget of the West Kazakhstan region, are also quantitatively calculated and justified. Budget indicators allow us to determine three levels of financial condition impacting on local budget.

It can be argued that result aimed at budgeting (hereinafter referred to as RBB) is a method of managing budget expenditures that leads to the targeted distribution of budget funds on the main points of state policy, through the provision of budget services to organizations and the population in order to achieve effective results in accordance with the budget expenditures made.

Keywords: budget, budget expenditures, budget policy, efficiency, effectiveness, indicator, planning.

\section{Introduction}

The government of any country develops strategic plans which calculate target indicators based on a large array of data. It also determines the amount of funding for a period of one year, three years, five years or more. During the determining an amount of funding, the priority is the effect of the implementation of this plan and indicators that can be used to make a conclusion about its achievement. Critical point which is taken into account in the process of making decisions is the fact that the priority is not the indicator of money allocated for budget expenditures, but the result achieved from their use, and indicators allow state bodies to achieve a well-coordinated work an effective result.

When our country started implementing the results-based state planning system, it also started implementing results-based budgeting, i.e. resultsbased budgeting (RBB) in parallel.

If we talk about the modern budget policy of our state, the novelty in market realities is that the republican budget not only includes expected indicators in various areas - education, tourism, labor, but also that the republican and local budgets are planned for a period of three years with an annual slide of one year ahead, and the budget funds are distributed among the administrators of budget programs, it is prescribed in the budget legislation. Why do we need these three years? 1. the planning horizon for budget programs is increasing; 2. a system of indicators of the effectiveness of budget expenditures is being developed; 3. optimal expenditures are being achieved; the work of the state body is being objectively evaluated; 4.the quality component of the draft republican budget is growing significantly, affecting the quality of local budgets.

Why is attention paid to the quality of planning and forecasting at the current stage of budget policy development? There is a direct link with the implementation of the budget strategy of the Republic of Kazakhstan, particularly with the quality components-efficiency and effectiveness, goals, sub-goals, tasks, and subtasks. Indicators are needed to assess their achievement and constant monitoring by the relevant authorities and society.

The purpose of the analysis is to study modern ways of using the system of indicators, its development and to justify the mechanism for implementing budget policy at the regional level using reasonable indicators (on example of the West Kazakhstan region). 


\section{Literature review}

The works of domestic and foreign scientists consider the identified problem related to the assessment of the state of the implemented budget policy, taking into account the constantly changing economic environment, there are also issues that continue to be actively discussed in the scientific community.

Basic research of the state budget is presented by Musgrave R. A. [1]. Willoughby K. G. [2] reveals the structure, process, and legal basis of the state budget on the example of the budgets of industrialized and developing countries. Schick A. [3] explores how a surplus turns into a deficit. A scientist asks a question: as the deficit continues to grow, will the state be able to fund such priorities as an effective army or taking care of aging population? The works of recognized foreign authors are devoted to the problems of efficiency of budget expenditures. Budget policy as the main tool for regulating the economy was justified by Keynes JM [4]. Hansen A. stated the priority of budget policy over monetary policy [5]. The distribution of government spending and taxation is analyzed in the works of Buchanan James M. [6]. The need to ensure a rational fiscal policy, the potential of countercyclical fiscal policy in mitigating negative consequences during a recession, and the possibility of improving fiscal policy tools in preparation for future downturns are presented by Hou Y. [7]. Garrett E., Graddy E. A., Jackson N. E. [8] indicate that state fiscal policy is much more vulnerable than the Federal budget. Therefore, the links between the budget policies of different countries are studied. Politicians need to understand how budget rules have evolved over time to respond to the world's crises. Government revenues and expenditures during business cycles are reviewed by Firestone JM. [9] Such scientists as Sun J., Lynch Thomas D. [10] have addressed the problem of forecasting revenues and expenditures, noting that budget estimates are often overlooked. A study of the scientific concept of "budgeting" have been studied by many scholars. Axelrod D. [11] laid a significant foundation for budgeting, pointing out that it reflects how much of the revenue goes to different government programs. Michiel S. de Vries, J. Nemec, and D. Prasek [12] provide a comparative analysis of the effectiveness of budgeting and financing, the strengths and weaknesses of budgeting in developed and developing countries. Miller G. J., Hildreth W. B., and Rabin J. [13] address the issue of results-based budgeting. Lee Jr. Robert D., Johnson R.W., Joyce P.G. [14] reviewed the current state of budgeting using the example of the US government. The authors emphasize the importance of using various types of information in making budget decisions, and the role of the federal government in the private sector. The government has become a major shareholder and therefore has a financial stake in the success of corporations. Khan A., Hildreth W. B. [15] contributed to the practice of budget management and budgeting under financial stress. These works are aimed at the developed market sector.

In the Republic of Kazakhstan, research on various aspects of the problem of theoretical and methodological justification of the "state budget" category was conducted by numerous researchers, but we must especially highlight those who significantly expanded this field of scientific activity - Melnikov V. D. [16], Nurmukhanova G. Zh. [17], Utibayev B. S. [18]. Domestic scientists in their research analyze not only the listed scientific problems. For example, Adambekova A., Intykbayeva S., Omirbayev S., Parmanov R. [19] provide scientific justification for budget issues at different levels of the budget - republican, regional, city, in the context of the crisis of the national economy and exit from it, the complexity of the functions of the state in the market economy which significantly affects strategic and operational planning, budget execution in conditions of unstable oil prices, depreciation of tenge. Ikhdanov $\mathrm{Zh}$. [20] studies multi-vector problems of budget management. Questions of the budget process are analyzed by K. K. Zhuirikov [21]. Elubayeva Zh. M. [22], Makarova N. A. [23] study the Kazakhstan budget system. The concept of public expenditures, the principles of their organization characterize Ilyasov K. K., Isakhova P. B. [24]. Modern budget policy of Kazakhstan is covered by Fadeikina N. V., Apsalyamov N. A., Azylkanova S. A. [25], Abdeshov D. D. [26]. Genesis of budget transfers, their essence is formed by R. M. Shaekin [27]. Taxes are the object of study in the works of Nurumov A. A., Bekbolsynova A. S. [28].

The achieved level of review of the theoretical and empirical base outlines the scientific field of activity for justifying the mechanism for implementing budget policy at the regional level, in order to legitimately analyze the level of efficiency and effectiveness of expenditures not only of local budgets, but also of the republican and consolidated budget.

\section{Methodology}

The methodology is based on a systematic approach. The system approach provides knowledge of the facts that determine the effectiveness and efficiency of budget expenditures.

Substantiation of theoretical positions and argumentation of conclusions and recommendations 
received in the course of the research were carried out on the basis of general scientific and special methods of scientific knowledge. The main methods of scientific knowledge used in the research are the following: synthesis of theory and practice, dialectics, empirical (collection, comparison and study of data), financial analysis of formal logic, classification, comparative analysis.

The use of these methods allowed us to ensure the reliability of the conclusions.

\section{Results and discussion}

The foundations of the modern theory of public finance arose in the late XIX - early XX centuries when the definition of the budget had begun to be associated with the concepts of supply and demand, as well as with the goods that are supplied by the authorities, that is, the state. At the same time, the first attempts to develop rational ways of budgeting were made. Over the years, the theory of public finance has become a real science, but it has mostly been considered only in terms of taxes and redistribution. And only nowadays we can observe a different view - a synthetic one. This approach examines the resources and activities of the state through the prism of production and barter of economic goods.

There are several indicators that determine the level of importance of public finance for the state:

- the consolidated budget and its level of expenditure on GNP/GDP;

- the role of the social sector in the consolidated budget;

- leading state or national projects and programs, their associated costs and their impact on investment;

- administrative cost;

- inter-budget transfers.

The Republic of Kazakhstan is currently using the concept of efficiency and effectiveness of budget expenditure planning. If earlier state bodies considered the degree of budget implementation as a concrete result, today another factor is taken into account - these are certain results that have social importance. In other words, the state refuses from the usual practice of formulating cost plan which indicate budget expenditures, the amount of funds allocated for public services in the field of strategically important areas for the state. The authorities have a different task - to analyze the expected results of the measures taken and approve budget requests only depending on the expected level of efficiency. Financing of budget expenditures is associated with their subsequent management (budget management). Budget management should be effective, since services are provided in important areas for society - health, education, and social security.

In the message from President KassymJomart Tokayev to the people of Kazakhstan "Constructive public dialogue-the basis for stability and prosperity of Kazakhstan" dated September 2, 2019 , it is indicated that the organization of the budget process should be reviewed at all levels national and local. The President emphasized the importance of real involvement of the population in the formation of local budgets, which is an absolute novelty for Kazakhstan's society. It is emphasized that the district, city and rural levels of government should become more economically independent in solving local problems, so the laws should specify their rights, duties and responsibilities [29].

One of the basic criteria for evaluating the effectiveness of budget spending is the correspondence between the indicators achieved as a result and the target values.

Today, in the sphere of the budget in the Republic of Kazakhstan, there is a tendency to modernize the activities of authorities, and close attention is paid to the assessment of the effectiveness of budget spending during this period. In economics, this term is also known by the abbreviation AEUBF - assessment of the effective use of budget funds. This assessment is based on the concept of three E-policies: these are the english-language terms economy, efficiency, and efficiency. AEUBF depends on indicators that identify the degree of effectiveness and efficiency of the state budget spending strategy.it is used when it is necessary to evaluate the effectiveness of an entire program, for example, budget or social. Thanks to the evaluation methods, you can analyze the impact of the program on the standard of living in society, the dynamics of the situation. If it is an economic program, the assessment will help to study its impact on the development of small or mediumsized businesses, but if it is an environmental project, the assessment system will reveal the level of its impact on changing the environmental picture in a particular region or country.

Chapter 9 "distribution of expenditures between budget levels" of the Budget code of the Republic of Kazakhstan contains article 54 "Expenditures of the regional budget". Expenses are financed in the following areas:

- state functions of a general nature - subject activity of the state, coordinated actions of the state mechanism;

- defense, public order, security - legally protected interests of society and the state, organization of protection of public order and security during mass events, when a state of emergency is imposed, for example, on March 16, 2020 in the Republic of Kazakhstan; 
- education-grants, NIS, school olympiads;

- healthcare - organization and provision of public health protection, screening, medical examination, vaccination;

- social assistance and social securitypayments to large families, rehabilitation of disabled people, pregnancy allowance;

- housing and communal services - lifesupporting environment, infrastructure for servicing residents, engineering networks;

- culture, sports, tourism and information space-museums, exhibitions, galleries, competitions, event (EXPO 2017) and youth tourism, information support of public administration;

- agro-industrial complex, water, forestry, specially protected natural territories, protection of the environment and wildlife, land relationssubsidies to farmers, study and accounting of forests, protection from fires, control over the use of forest resources, tasks related to water supply of the country's population, work with aquatic flora and fauna, reserves, reserves, botanical gardens, national and natural parks, health and recreation areas and resorts, relations in the implementation of land law;

- architectural, urban planning and construction activities - urban planning regulations, standards in the field of architecture, licensing;

- transport and communications-main and industrial transport system, communication routes, communication networks, technical means and services;
- regulation of economic activity-laws, state orders, monetary and fiscal policy;

- other directions.

As you can see, budget expenditures contribute to the implementation of numerous budget measures.

The budget in the country is projected for three years, and the forecast budget parameters are indicative for the second and third years of the planning period. Indicators are not fixed, they are refined when developing a forecast of budget parameters for the next planning period.

To evaluate the achievement of planned results in budget expenditures, an algorithm using indicators is needed to make a conclusion about the validity, efficiency, necessity, and effectiveness of budget expenditures. The algorithm should be specialized, taking into account the specifics of the budget process. The analysis of scientific literature has led to the conclusion that the result-oriented budget is associated with a method (a system of indicators) that allows a balanced assessment of both social and economic efficiency of budget expenditures [30].

Tables 1,2,3 contain an informative quantitative assessment of the level of financial stability and security of the local budget. The calculations use indicators of budget symmetry (table 1), revenue potential (table 2) and budget security (table 3 ) for a longer period of time to reliably assess the indicators under consideration.

Table 1 - Indicators of budget symmetry of local budgets and their critical values in accordance with budget legislation

\begin{tabular}{|c|c|c|c|}
\hline \multicolumn{4}{|c|}{ Indicators budget of symmetry } \\
\hline $\begin{array}{l}\text { Debt limit of the local } \\
\text { executive body }\end{array}$ & $\begin{array}{l}\text { Total amount of the } \\
\text { reserve of the local } \\
\text { executive body }\end{array}$ & $\begin{array}{l}\text { Compliance of current } \\
\text { expenditures with the volume } \\
\text { of budget revenues }\end{array}$ & Budget deficit \\
\hline \multicolumn{4}{|c|}{ Critical values } \\
\hline $\begin{array}{l}\text { Fixed amount of received } \\
\text { and outstanding loans by } \\
\text { the local executive body for } \\
\text { the corresponding financial } \\
\text { year. This amount should } \\
\text { not exceed the actual debt } \\
\text { of the local executive body } \\
\text { on the specified date. This } \\
\text { is usually the end of the } \\
\text { corresponding fiscal year }\end{array}$ & $\begin{array}{l}\text { It must not exceed } 2 \% \\
\text { of the corresponding } \\
\text { local budget revenue. } \\
\text { Transfers and loans are } \\
\text { not counted }\end{array}$ & $\begin{array}{l}\text { Compliance of approved } \\
\text { (updated, adjusted) budget } \\
\text { indicators with approved } \\
\text { (adjusted) parameters, } \\
\text { directions of socio-economic } \\
\text { development forecasts, and } \\
\text { strategic plans of state bodies }\end{array}$ & $\begin{array}{l}\text { (Loans received+ } \\
\text { budget balances used)> } \\
\text { (Repayment of principal } \\
\text { on loans). The excess } \\
\text { amount is defined as the } \\
\text { amount of funding for the } \\
\text { budget deficit }\end{array}$ \\
\hline \multicolumn{4}{|c|}{ Budget code of the Republic of Kazakhstan } \\
\hline Chapter 1 , article 3 & Chapter 4, article 19 & Chapter 1, article 4 & Chapter 3 , article 18 \\
\hline
\end{tabular}


Table 1 shows that the indicators of fiscal symmetry related to the debt limit, reserve, optimality of income and expenditure, and lack of money are characterized by critical values in accordance with the national budget law.

Table 2 shows that the critical value for the three indicators is the lowest indicator for the study period. The critical values correspond to Chapter 1 "General provisions" of article 4 "Principles of the budget system of the Republic of Kazakhstan" of the Budget Code of the Republic of Kazakhstan.
This article reveals two ways to implement the principle of efficiency:

1) Achieving the best direct result using the approved amount of budget funds.

2) The fchievement of direct result with use of smaller volume of budgetary funds.

Own income is present in the first and second indicators, since tax revenues are estimated at $85 \%$ to $95 \%$ of budget revenues.

Indicators of budget security of local budgets include 4 indicators (table 3 ).

Table 2 - Indicators of revenue potential of local budgets and their critical values

\begin{tabular}{|l|l|c|c|}
\hline № & Indicators of revenue potential & Unit & Critical values \\
\hline 1 & Own revenues / Revenues of the local budget & $\%$ & \multirow{2}{*}{ Lowest rate } \\
\hline 2 & Own revenues of the local budget / Number of population & tenge & \\
\hline 3 & Execution of the local budget by revenue & $\%$ & \\
\hline \multicolumn{2}{|l|}{ Note: compiled by the authors } & \\
\hline
\end{tabular}

Table 3 - Indicators of budget security of local budgets and their critical values

\begin{tabular}{|l|l|l|}
\hline № & \multicolumn{1}{|c|}{ Indicators of budget security } & \multicolumn{2}{|c|}{ Critical value } \\
\hline 1 & $\begin{array}{l}\text { Balance of the local budget (matching expenditures with local } \\
\text { budget revenues) deficit ( }- \text { ) or surplus (+) }\end{array}$ & $\begin{array}{l}\text { A level that does not meet financial } \\
\text { standards for socially significant } \\
\text { expenditures }\end{array}$ \\
\hline 2 & $\begin{array}{l}\text { Budget provision for expenditures on social and cultural events } \\
\text { per 1 resident, tenge }\end{array}$ & Lowest rate \\
\hline 3 & $\begin{array}{l}\text { Expenditures on social and cultural events / Local budget } \\
\text { expenditures, \% }\end{array}$ & $\begin{array}{l}\text { The elasticity of social spending relative to the income of the local } \\
\text { budget of (Ee) }\end{array}$ \\
\hline Note: compiled by the authors & \\
\hline
\end{tabular}

From table 3 it can be seen that the indicators of budget sufficiency describe the system of public finance through fiscal policy.

Let's calculate indicators for analyzing the state of the local budget on the example of the West Kazakhstan region:

1. Indicator of budget policy, which characterizes the degree of non-subsidized development of the region. expenses

Tax-free development $=$ own income/own

201738726998 thousand tenge/130 889 863 thousand tenge $=0.29$ tenge

201839933253 thousand tenge/118 220 843 thousand tenge $=0.34$ tenge

201942771594 thousand tenge/156 429 643 thousand tenge $=0,27$ tenge

The indicator gives an overall assessment of the liquidity of budget assets (revenues). In practice, it shows how many monetary units of income account for one tenge of expenditure obligations. The calculation of the indicator for three years showed that the level of flotation-free development of the West Kazakhstan region was the lowest in the reporting period of 0.27 tenge, the highest in 2018 of 0.34 tenge. Own income, which is the basis for calculating the indicator, is the sum of tax and non-tax payments. These payments are $100 \%$ or a certain percentage assigned by regulatory decrees to the local budget. Local authorities can decide to consolidate the new charges. Currently, the $\mathrm{BC}$ of the Republic of Kazakhstan does not contain the interpretation of its own income. In order for revenues to be included in their own, it is necessary to comply with the conditions that have a concentrated expression in budget policy: the feasibility of stating mandatory elements of taxation; full or fixed part of the inclusion of income in the relevant territorial budget on a longterm basis; objective impact of state authorities 
and / or local authorities on the formation of the revenue base; place of formation of the revenue base within the administrative-territorial divisions; development of its own revenue (tax) base.

2. Financial independence of the local budget $=$ necessary expenses-own expenses $2017130889863-38726998=92162865$ thousand tenge,

2018118220843 - 39 933=118 180910 thousand tenge,

2019156429643 - $42771594=113658$

049 thousand tenge.

The higher the indicator value, the higher the financial independence from higher authorities. The 2019 indicator is $23.3 \%$ higher than the 2017 indicator, but 3.8\% lower than the 2018 level, which indicates a deterioration in the efficiency of local tax administration in the studied region.

3. The indicator of autonomy or concentration of own funds (or stability, security, independence) characterizes the financial state of the local budget in terms of security and independence. A low indicator value indicates that the region is financially unstable, unstable, and dependent on higher-level budgets.

Autonomy or concentration of own funds $=$ Own income/Revenues of the local budget

The share of own income in the structure of local budget revenues for the study period was:

201738726998 thousand tenge/123 820 794 thousand tenge $=31,3 \%$

201839933253 thousand tenge/118 264 781 thousand tenge $=33,8 \%$

201942771594 thousand tenge/155 702 433 thousand tenge $=27,5 \%$

The highest indicator indicates the best financial condition of the local budget system, and the growth of the indicator in dynamics is a positive trend. During the study period, the opposite situation is the negative trend of reducing own income from $31.3 \%$ in 2017 to $27.5 \%$ in 2019 , a decrease of $3.8 \%$.

4. The indicator of financial dependence of the local budget is the reciprocal of the coefficient of autonomy of local budgets.

Currently, there is no single point of view on the size of the critical value of the structural weight of own funds in the total amount of budget revenues. Most scientists agree with the value of 0.5 . This is explained by the fact that at least $50 \%$ of budget revenues should practically be formed from their own income payments, i.e. tax and nontax revenues. budget:

Indicator of financial dependence of the

201785082796 thousand tenge/123 820 794 thousand tenge $=68.7 \%$,
$201878,321,728$ thousand tenge/ $118,264,781$ thousand tenge $=66.2 \%$,

2019112910303 thousand tenge/155 702 433 thousand tenge $=72.5 \%$.

Financial dependence on higher-level budgets is present, since the value is higher than $50 \%$. The degree of financial dependence of the subject on the republican budget in 2019 is higher.

Autonomy or concentration of own funds + Financial dependence of the local budget $=1$ or $100 \%$.

The sum of the indicator of autonomy and the indicator of financial dependence of the local budget:

$201731.3 \%+68.7 \%=100.0 \%$;

$201833.8 \%+66.2 \%=100.0 \%$;

$201927.5 \%+72.5 \%=100.0 \%$. of $100 \%$.

The fiscal year corresponds to a critical value

5. The indicator of the ratio of own and borrowed assets characterizes the stability of the earning capacity of the regional budget.

Indicator $=$ own budget funds/raised funds

Critical value: $0<$ to own/ loaned of $<2$.

201738726 998/85 082 796 $=0.45$

$201839933253 / 78321728=0.51$

$201942771594 / 112910303=0.38$

Indicators less than 1 mean a greater dependence on attracting budget revenues. A value greater than 1 characterizes the strengthening of budget stability and independence of territories. A decrease in the indicator in dynamics means an increase in the dependence of the local budget on higher-level budgets and other sources of financing its deficit, and vice versa. The indicator is decreasing from 0.45 in 2017 to 0.38 in 2019.

6 . The indicator of budget deficit.

Budget deficit $=$ Absolute budget deficit (surplus)/Budget expenditures

The indicator indicates the effectiveness of financial policy, so it is important to indicate the maximum value, while the norm is considered to be a non-negative value. The presence of a deficit is not negative; this provision is used in the laws of some countries. There may be a moderate deficit in the budget. Objective parameters of moderate deficit are also of constructive significance. A moderate deficit increases budget expenditures with a multiplicative effect, accumulates temporarily available financial resources to cover them, provides authorities with real revenue resources, motivates orders for services and works for budget institutions, leads to the achievement of economic and social effects at a certain stage, creates new jobs at the expense of budget funds, activates demand and supply. The understanding of these economic dependencies led to the adoption of the financial stability pact by the 
Gulnara K. Kurmanova, Bibigul B. Sukhanberdina, Bakit A. Urazova,

European Union countries in 1997 on the initiative of Germany. The pact limited the deficit to $3 \%$ of the actual GDP, and the inflation rate in any country of the monetary union is not higher than the level prevailing in the three most stable countries - 2.0$3.5 \%$ per year.

The indicator of budget deficit:

$2017-13211437$ thousand tenge/130 889

863 thousand tenge $=-0.10 \%$

2018 -9 419404 thousand tenge/118 220843 thousand tenge $=-0,08 \%$

$2019-12428308$ thousand tenge /156 429 643 thousand tenge $=-0,08 \%$

In none of the periods has the target nonnegative criterion been reached - in all years, negative values are reduced from -0.10 to- 0.08 by the reporting period. the budget of the West Kazakhstan region is negatively affected by the growth of the budget deficit in 2019, which exceeds the deficit in 2018. We agree with the opinion of experts who claim that budget deficits and surpluses do not contribute to the stability and stability of the financial system, since the functions of the state are not implemented in $100 \%$ of the deficit, and when there is a surplus, financial resources are reduced for the implementation of state tasks.

7. Indicator balanced budget.

The ratio of income and expenditure that determines the budget deficit/surplus, i.e. its balance, is another indicator of the financial stability of the territorial budget system. Critical value: $3 \%$ of the deficit in absolute terms to the gross regional product.

Balanced budget $=$ Revenue/Expenses

The balance indicator of the budget of the West Kazakhstan region was:

$2017-13,211,437$ thousand tenge/2,232,8 thousand tenge $=0.059 \%$

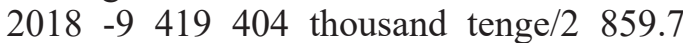
thousand tenge $=0.033 \%$

$2019-12,428,308$ thousand tenge/2,099. 9 thousand tenge $=0.059 \%$

The calculated data prove the balanced development of the region, as the indicators are below $3 \%$.

The balance of the budget should not be based on the principle of "expenses by income", which was present before the introduction of the RBB. Now the leading role of expenditures in relation to income has been adopted: we should not reduce expenditures, especially in the social sphere, but should strive to identify reserves for increasing additional income by increasing our own income, legalizing the "shadow" economy, and rationalizing financial assistance to the region.

The indicator has a weak side - it does not fully reflect the financial stability of the territorial budget system. This is due to the fact that the indicator fixes the state of the budget for a certain time period, but the outlook, taking into account the long - term financial strategy for the development of the region, is not. This fact affects the fact that the stability of the budget cannot be characterized only by balance, because:

1) A balanced budget does not encourage akimats to search for additional sources of budget revenue generation, increase financial resources, which does not allow achieving budget policy goals as effectively as possible.

2) The budget structure, planned and achieved indicators of the balanced budget of the current period are not an accurate and objective guide for subsequent periods, as they change: the establishment of optimal proportions of distribution of funds between centralized and decentralized funds; branches of the national economy and administrative divisions; external and internal factors that affect the financial situation in the region. For example, economic growth, cyclicality, investment volume, inflation rate, exchange rate, refinancing rates, labor productivity level, decline (rise) in production, volume of digitalization of the economy, unemployment rate, etc.

3) Balance at the stage of budget formation due to inefficient financial management by authorities may lead to non-execution of the budget due to inappropriate use of resources, lack of necessary reserves in accordance with the goals of budget policy.

4) Balance is not expressed quantitatively, it is a qualitative principle of full coverage of expenditures by budget revenues, which is transformed into the development of new planning methods, the choice and definition of budget planning tools.

8. Indicator of subsidization.

Subsidization=Transfers/Own income

Used for estimating the revenue side of the budget. Critical values cannot be determined, which is related to the nature of grants. Since subsidies are the allocation of money from the budget on a free basis, local authorities may be interested in a high level of subsidies. Budget in practice there are associated grants, study subsidies allows us to characterize the degree of development of budgetary relations. What distinguishes linked grants from regular ones is that they are provided only under the condition of financing certain types of expenditures using them, which can reduce the financial mobility of the local budget. As a condition for granting grants, the higher budget has the right to require the lower budget to fulfill its conditions. This deprives the local government of a significant share of independence in decision-making, which 
practically does not take into account the budget execution by sources of financing the budget deficit, which, accordingly, cannot provide for achieving a balanced budget in the process of its execution.

A similar indicator is considered to be the donation of the local budget.

The donation of the local budget=Tax payments to the budgets of higher levels/Transfers from these budgets

The critical value of the indicator is $>1$.

Indicator of subsidized budget:

$2017 \quad 85 \quad 0827961$ tenge/38 $726 \quad 9981$ tenge $=219.7 \%$

$201878 \quad 321 \quad 7281$ tenge/39 $933 \quad 2531$ tenge $=196.1 \%$

20191129103031 thousand tenge/42 771 5941 thousand tenge $=263.9 \%$

The subsidized budget is increasing from $219.7 \%$ in 2017 to $263.9 \%$ in 2019 , with an increase in subsidies of $44.2 \%$.

The specificity of the organizational aspect of budget execution implies a non-taxable development. In other words, the functioning of the socio-economic sphere of the local budget is ensured on the basis of its own revenues within the established and transferred rights and powers of local self-government bodies, while achieving state minimum social standards and unconditionally fulfilling expenditure obligations. Tax-free development leads to increased financial discipline and an increase in the quality of budget execution.

9. Indicator of the region's budget performance.

Budget performance of the region=Own revenues of budget/Average annual population of the region

Estimates of the budgetary impact:

201738726998 thousand tenge/646 927 thousand. $=59863$ tenge

201839933253 thousand tenge/652 314 thousand. $=61218$ tenge

201942771594 thousand tenge/656 974 thousand people $=65104$ tenge

Budget performance increases over the years from 59,863 tenge in 2017 to 65,104 tenge in 2019, an increase of 5,241 tenge or $8.7 \%$.

10. Indicator budget coverage.

Budget coverage $=$ Total revenue $/$ Total expenditure

Critical value: close to one.

In accordance with article 11 "Budget Revenues" of Chapter 3 "budget Structure" of the $\mathrm{BC}$ of the Republic of Kazakhstan, budget revenues are revenues: tax, non - tax, from the sale of fixed capital, transfers.
The increased budget coverage:

2017123820794 thousand tenge/130 889 863 thousand tenge $=94,6 \%$

2018118264781 thousand tenge/118 220 843 thousand tenge $=100,0 \%$

2019155702433 thousand tenge/156 429 643 thousand tenge $=99,5 \%$

Only the 2018 indicator corresponds to the critical value of $100 \%$. In 2017 and 2019, the region was not financially independent-a value less than 1 is 0.946 and 0.995 , respectively, i.e. total revenues are lower than total expenses.

11. Indicator of budget security of the population.

Budget security of the population=Budget expenditures/Average annual population of the region population:

Coefficient of budget security of the

2017 130,889,863 thousand tenge/646,927 thousand tenge $=202,325$ tenge

2018118220843 thousand tenge/652 314 thousand tenge $=181233$ tenge

2019156429643 thousand tenge/656 974 thousand tenge $=238106$ tenge

Calculations show that the budget security of the population is higher in 2019 compared to 2017 by 35,781 thousand tenge or $17.7 \%$.

12. Indicators of the structure of local budget expenditures.

Structure of local budget expenditures $=$ Articles or groups of articles of consumption/Total amount of local budget expenditures

The share of the development budget and the share of expenditures on social policy and housing and utilities are the main indicators in this group. The share of expenditures on social policy in the region was:

$201744,815,872$ thousand tenge $/ 130,889,863$ thousand tenge $=32.4 \%$

201830567448 thousand tenge/118 220 843 thousand tenge $=25.8 \%$

201947105854 thousand tenge/156 429 643 thousand tenge $=30.1 \%$

The budget security of the population decreased from $32.4 \%$ in 2017 to $30.1 \%$ in 2019 , but there is an increase in the reporting year compared to 2018 by $4.3 \%$.

Local budgets with insufficient funds to finance social programs do not implement investment programs, which complicates the implementation of growing basic social obligations to the population. Therefore, the growth of the share of the development budget is an effective indicator. The increase in the share of expenditures on the social sphere indicates a positive or negative trend 
Gulnara K. Kurmanova, Bibigul B. Sukhanberdina, Bakit A. Urazova,

/ Экономика: стратегия и практика, № 3 (15), 2020 г.

of using budget policy as a stabilization tool - an increase in funding for social programs and housing and communal services, or a reduction in funding for other programs. Therefore, the dynamics of this indicator should be compared with the dynamics of the indicator of expenditures per capita in the region.

13. Budget security per 1 resident for expenditures on social and cultural events:

201744815872 thousand tenge/646 927 people $=69275$ tenge $/$ person
201830567448 thousand tenge/pers. 652 $314=46860$ tenge /person

201947105854 thousand tenge/656 974 people $=71701$ tenge $/$ person

The budget provision per 1 resident for expenditures on social and cultural events was the highest in 2019 and amounted to 71,701 tenge, which is higher than in 2018 by 24,841 tenge or $53.0 \%$.

The calculation of the elasticity of sociocultural expenditures in relation to local budget revenues is the basis for justifying the priority directions of budget policy.

Table 4 - Initial data for calculating the elasticity of socio-cultural expenditures in relation to local budget revenues, thousand tenge

\begin{tabular}{|l|c|c|c|c|}
\hline \multicolumn{1}{|c|}{ Indicator } & 2016 & 2017 & 2018 & 2019 \\
\hline Social and cultural expenses & 47713090 & 44815872 & 30567448 & 47105854 \\
\hline including on: & & & & \\
\hline education & 12984002 & 23797369 & 17283427 & 24589625 \\
\hline healthcare & 27710246 & 15048032 & 3612332 & 3749664 \\
\hline social assistance and social security & 2347390 & 3855521 & 4418966 & 12220482 \\
\hline $\begin{array}{l}\text { culture, sports, tourism and information } \\
\text { space }\end{array}$ & 4671452 & 5624429 & 5252723 & 6546083 \\
\hline Arithmetic mean simple & & 46264481 & 37691660 & 38836651 \\
\hline Revenue & 123262773 & 123820794 & 118264781 & 155702433 \\
\hline Arithmetic mean simple & & 123541784 & 121042788 & 136983607 \\
\hline \multicolumn{2}{|l|}{ Note: compiled by the authors } & & & \\
\hline
\end{tabular}

$$
\begin{aligned}
& \text { Ee } 2017 \frac{44815872-47713090 / 46264481}{123820794-123262773 / 123541784}=\frac{-0,063}{0,005}=-12,6 \\
& \text { Ee } 2018 \frac{30567448-44815872 / 37691660}{118264781-123820794 / 121042788}=\frac{-0,378}{0,046}=-8,22 \\
& \text { Ee } 2019 \frac{47105854-30567448 / 38836651}{155702433-118264781 / 136983607}=\frac{0,426}{0,273}=1,56
\end{aligned}
$$

In 2019 , the elasticity value is greater than 1 , and when budget revenues increase, this means a highly significant budget spending direction. The growth rate of expenses is higher than the growth rate of income. In 2018 Ee is less than 1, with decreasing revenues, this means a significant budget for the area of spending. There is a steady increase in expenses, depending on the growth of income. In 2017 Ee is less than 1, with increasing revenues, this means low significant area of expenditure. Spending in this area is growing, but at a slower rate than income is growing.

To calculate the financial stability of regional budgets, a score is used. The score justifies the direction of the budget strategy of the region through positioning the state of the local budget. There are three degrees of financial stability and security of the local budget based on indicators:

- unreliable financial condition of the local budget;

- unreliable (unstable);

- reliable (stable) financial condition of the local budget.

The precarious financial status of the local budget is characterized by the maximization of fiscal risks; the inability to ensure fiscal security of 
the region; low level of own sources of formation of the budget; the imbalance in fiscal relations in the region; low index of tax capacity; inability to collect in the region approved income, which reduces the self-development of the territory; a small share of social spending in total expenditures.

The unreliable (unstable) financial state of the local budget is characterized by a negative trajectory of public finances; insufficient own income for sustainable development; negative income dynamics; low elastic growth of expenditures on social and cultural events depending on income growth, which indicates their insufficiency; low opportunities for financing investment and innovative development and social orientation of the regional economy.

Reliable (stable) financial state of the local budget is distinguished by the expansion of the revenue base of the region; harmonization of the fiscal relations at the regional level; a single loop and interconnection of interests of all levels of government; sufficient equity sources of income; the balance of the local budget; funding priority socio-cultural sphere; creation of conditions for development of entrepreneurial activities and economic growth and balancing the interests of the state, regions, local entities and all members of society; absolute tax independence; minimization of budget risks; development of a budget strategy that allows for reasonable differentiation of budget powers to ensure self-development of the territory; effective operation and implementation of the functions of government bodies to achieve strategic goals of socio-economic development.

Based on theabove, we formulate the definition of the stability of the territorial budget system as a state of budget balance that provides conditions for the self-development of local administrative and territorial units and the effectiveness of budget expenditures of a social orientation. In the budgetary system of federal and unitary states, the importance of budget expenditures is not in doubt. Increasing or decreasing budget expenditures affect the mechanism of implementation of state policy.

The indicators calculated using the algorithm of tables 1,2,3,4 are summarized in table 5 .

Table 5 - Critical values of indicators of revenue potential and budget security of the budget of the West Kazakhstan region in the period 2017-2019

\begin{tabular}{|c|c|c|c|c|c|}
\hline Indicator & $\begin{array}{l}\text { Minimum } \\
\text { value }\end{array}$ & $\begin{array}{l}\text { Maximum } \\
\text { value }\end{array}$ & $\begin{array}{l}\text { Unreliable } \\
\text { financial } \\
\text { condition }\end{array}$ & $\begin{array}{l}\text { Unreliable } \\
\text { (unstable) } \\
\text { financial } \\
\text { condition }\end{array}$ & $\begin{array}{l}\text { Reliable } \\
\text { (stable) } \\
\text { financial } \\
\text { condition }\end{array}$ \\
\hline $\begin{array}{l}\text { Own revenues / Revenues of the } \\
\text { local budget, } \%\end{array}$ & $27,5 \%$ & $33,8 \%$ & $<=27,5 \%$ & $20 \%-31,3 \%$ & $>=31,3 \%$ \\
\hline $\begin{array}{l}\text { Own revenues of the local budget / } \\
\text { Number of population, tenge }\end{array}$ & 59863 & 65104 & $<=59863$ & $59863-61218$ & $>=61218$ \\
\hline $\begin{array}{l}\text { Execution of the local budget by } \\
\text { revenue, } \%\end{array}$ & $96,6 \%$ & $105,3 \%$ & $<=96,6 \%$ & $96,6 \%-100 \%$ & $>=100 \%$ \\
\hline $\begin{array}{l}\text { Balance of the local budget } \\
\text { (matching expenditures with local } \\
\text { budget revenues) deficit } \\
(-) \text { or surplus }(+)\end{array}$ & -9419404 & $\begin{array}{c}-13211 \\
437\end{array}$ & $<0$ & - & $>=0$ \\
\hline $\begin{array}{l}\text { Budget provision of the population, } \\
\text { tenge }\end{array}$ & 181233 & 238106 & $<=181233$ & $181233-202325$ & $>=202325$ \\
\hline $\begin{array}{l}\text { Budget provision for expenditures } \\
\text { on social and cultural events per } 1 \\
\text { resident, tenge }\end{array}$ & 46860 & 71701 & $<=46860$ & $46860-69275$ & $>=69275$ \\
\hline $\begin{array}{l}\text { Expenditures on social and cultural } \\
\text { events / Local budget expenditures, } \\
\%\end{array}$ & $25,8 \%$ & $32,4 \%$ & $<=25,8 \%$ & $25,8 \%-30,1 \%$ & $>=30,1 \%$ \\
\hline $\begin{array}{l}\text { The elasticity of social spending } \\
\text { relative to the income of the local } \\
\text { budget of }\end{array}$ & $-12,6$ & 1,56 & $<=-12,6$ & $-12,6-1$ & $>=1$ \\
\hline
\end{tabular}


The analysis of the calculated indicators of financial stability of local budgets for compliance with critical ones showed that the financial condition of the budget of the West Kazakhstan region is reliable (stable).

Verification of the received final data proves that the stability of the budget reflects the positive financial situation of the state as a whole. An extremely balanced and competent analysis of budget stability by investors is required to assess the budget risk of capital investment in the region.

The budget must have a sufficient margin of safety created by a stable growth of the tax base, i.e. the indicator of the quality of budget policy is associated with the «high base» effect. Financing of existing obligations with regard to results-based budgeting is possible with stable performance of the revenue part of the budget.

A balanced assessment of revenues and expenditures of three-year budgets, the main budget and quasi-budget parameters, ensures social and economic stability in the region.

\section{Conclusion}

In modern conditions of budget policy implementation, the importance of planning and monitoring is further enhanced in order to improve management in the sphere of ensuring "productive" budget expenditures, which is reflected in expert assessments of budget execution, the formation of a further strategy for budget development, taking into account forecast assessments of the macroeconomic situation. The emphasis has shifted to the definition of "achieved result", "not achieved result", "effect of achieved result", and not to the actual spending of budget money.

Based on the conducted research, the purpose of which was to study modern ways and justification of the mechanism for implementing budget policy at the regional level using reasonable indicators, it is possible to justify the conclusions.

RBB is the achievement of an optimal balance between implemented public expenditures and social results. Therefore, when developing, refining, adjusting, and executing budgets at all levels, authorized bodies and administrators of budget programs should proceed from the following. 1. The need to achieve the desired results using the smallest amount of funds. Or 2. Achieving the best result using the amount of funds determined by the budget.

The system of indicators allows you to evaluate the effectiveness of budget money, and when comparing planned and actual indicators, make reasonable conclusions.

The economic territorial development of the state has a direct impact on the level of budget expenditures. Budget policy seeks to level out the inequality in the amount of funding in order to equalize the regions in terms of socio-economic development. Therefore, local budget expenditures in any country are an active tool of state influence on socio-economic processes. The economic territorial development of the state has a direct impact on the level of budget expenditures. Budget policy seeks to level out the inequality in the amount of funding in order to equalize the regions in terms of socioeconomic development. Therefore, local budget expenditures in any country are an active tool of state influence on socio-economic processes.

\section{References}

1 Musgrave R.A. (1959) Theory of public finance. - New York, Toronto, London: McGraw-Hill Book Company Inc., 628

2 Willoughby K.G. (2014) Public Budgeting in Context: Structure, Law, Reform and Results. - San Francisco, CA:Jossey-Bass, 454

3 Schick A.(2008) The Federal Budget: Politics, Policy, Process. Brookings Institution Press, Washington, D.C., 345

4 Keynes JM (2012) The general theory of employment, interest and money. Cambridge University Press, 450

5 Hansen A. (1941) Fiscal policy and business cycles. W.W. Norton, New York, 468

6 Buchanan J.M. \& Musgrave R.A. (1999) Public Finance and Public Choice. Two Contrasting Visions of the State. Cambridge, Massachusetts: The MIT Press, 272

7 Hou Y. (2013) State Government Budget Stabilization: Policy, Tools, and Impacts. SpringerVerlag New York, 356

8 Garrett E., Graddy E.A., Jackson H.E. (2008) Fiscal Challenges: An Interdisciplinary Approach to Budget Policy. / E. Garrett, E.A. Graddy, H.E. Jackson. Cambridge University Press, 471

9 Firestone JM. (1961) Federal receipts and expenditures during business cycles 1879-1958, National Bureau of economic research, studies in business cycles series. 9. Princeton: Princeton University Press. Pp. xvi, 176.

10 Sun J., Lynch T.D.(2008) Lynch Government Budget Forecasting: Theory and Practice (Public Administration and Public Policy). Taylor \& Francis Group, LLC, New York, 664

11 Axelrod D. (1995) Budgeting for modern government. St. Martin's Press, New York, 464

12 Michiel S. de Vries, Nemec J., Spacek D. (2019) Performance-Based Budgeting in the Public Sector. / S. de Vries Michiel, J. Nemec, D. Spacek. Springer International Publishing; Palgrave Macmillan, 279

13 Miller G.J., Hildreth W.B., Rabin J. (2001) Performance-Based Budgeting: an ASPA Classic. / 
G.J. Miller, W.B. Hildreth, J. Rabin. Oxford: Westview Press, 504

14 Robert D. Lee Jr., Johnson R.W., Joyce P.G. (2012) Public Budgeting Systems. / D. Lee Jr. Robert, R.W. Johnson, P.G. Joyce. Jones \& Bartlett Learning, 667

15 Khan A., Hildreth W.B. (2003) Case Studies in Public Budgeting and Financial Management. Basel, Switzerland, CRC Press, 837

16 Mel'nikov V.D. (2015) Teorija finansov: uchebnoe posobie. Almaty: LEM, 400. (in Russ.).

17 Nurmuhanova G.Zh. (2001) Gosudarstvennyj bjudzhet: ucheb.posobie. Karaganda: Bolashaқ-Baspa, 136. (in Russ.).

18 Utibaev B.S. (2006) Gosudarstvennyj bjudzhet: uchebnik / B.S.Utibaev, R.M. Zhunusova, V.A. Satkalieva. Almaty: 'Ekonomika, 412. (in Russ.).

19 Omirbaev S.M., Intykbaeva S.Zh., Adambekova A.A., Parmanova R.S. (2011). Gosudarstvennyj bjudzhet: uchebnik. / S.M. Omirbaev, S.Zh. Intykbaeva, A.A. Adambekova, R.S. Parmanova. Almaty: TOO RPIK «Douir», 632. (in Russ.).

20 Ihdanov Zh. (2007) Memlekettik baskaru teorijasy / Zh. Ihdanov, Sansyzbaeva G.N., Esenzhigitova R.G. Almaty.: 'Ekonomika, 216. (in Kaz).

21 Zhujrikov K.K. (2003) Bjudzhet: sostavlenie, utverzhdenie, ispolnenie: Uchebnoe posobie. Almaty: Almatinskaja akademija `ekonomiki i statistiki, 210. (in Russ.).

22 Elubaeva Zh.M. (2004) Bjudzhetnaja sistema RK: teorija, praktika i napravlenija razvitija. Almaty, 346. (in Russ.).

23 Makarova N.A. (2008) Bjudzhet i bjudzhetnaja sistema: Astana: Foliant, 371. (in Russ.).

24 Il'jasov K.K., Isahova P.B. (2003) Rashody gosudarstvennogo bjudzheta: Uchebnoe posobie. Almaty: `Ekonomika, 290. (in Russ.).

25 Fadejkina N.V., Apsaljamov N.A., Azylkanova S.A. (2009) Sovremennaja bjudzhetnaja politika Kazahstana. / N.V. Fadejkina, N.A. Apsaljamov, S.A. Azylkanova. Novosibirsk: SIFBD, 299. (in Russ.).

26 Abdeshov D.D. (2004) Formirovanie novoj sistemy prioritetov bjudzhetnoj politiki na sovremennom 'etape // Finansy Kazahstana. 6, 32-36. (in Russ.).

27 Shaekin R.M. (2004) Bjudzhetnye transferty v fiskal'no-raspredelitel'nom mehanizme Respubliki Kazahstan. Karaganda: TOO «Arko», 122. (in Russ.).

28 Nurumov A.A., Bekbolsynova A.S. (2009) Nalogi i nalogooblozhenie: uchebnik. Astana: Izd. KazU'EFiMT, 583. (in Russ.).

29 Poslanie Glavy gosudarstva KasymZhomarta Tokaeva narodu Kazahstana «Konstruktivnyj obshchestvennyj dialog - osnova stabil'nosti i procvetaniya Kazahstana» ot 2 sentyabrya, 2019. (in Russ.).

30 Kurmanova G.K., Mashanova S.A., Salimbaeva Sh.D. (2016) Kazirgi zamanғy bjudzhet sajasatynyң indikatorlary. / G.K. Kurmanova, S.A. Mashanova, Sh.D. Salimbaeva. Tranzitnaja `ekonomika. 2, 77-84. (in Kaz.). 